\title{
PENGARUH PERBEDAAN KONSENTRASI GELATIN CEKER AYAM KAMPUNG TERHADAP KARAKTERISTIK FISIK EDIBLE FILM
}

\author{
Sukma W Asmudrono, M. Sompie*, S. E. Siswosubroto, J. A. D. Kalele \\ Fakultas Peternakan Universitas Sam Ratulangi Manado 95115
}

\begin{abstract}
ABSTRAK
Penelitian ini bertujuan untuk menentukan pengaruh perbedaan konsentrasi gelatin ceker ayam kampung terhadap karakteristik fisik edible film. Penelitian ini menggunakan Rancangan Acak Lengkap (RAL) dengan perlakuan konsentrasi gelatin ceker ayam kampung $(5 \%, 10 \%, 15 \%, 20 \%)$ masing-masing perlakuan diulang sebanyak empat kali ulangan. Hasil penelitian menunjukkan bahwa pengaruh perbedaan konsentrasi gelatin ceker ayam kampung memberikan pengaruh yang berbeda nyata $(\mathrm{P}<0,05)$ terhadap nilai kekuatan tarik, kemuluran, ketebalan edible film. Berdasarkan hasil pembahasan dapat disimpulkan bahwa konsentrasi gelatin ceker ayam kampung dari semua variable dengan konsentrasi gelatin 10\% menghasilkan karakteristik fisik edible film yang baik.
\end{abstract}

Kata kunci: Ceker ayam, Edible film, Gelatin

\begin{abstract}
THE EFFECT OF DIFFERENCES CONCENTRATION OF NATIVE CHICKEN CLAW GELATIN ON THE PHISYCAL CHARACTERISTICS OF EDIBLE

FILM. This study aims to determine the effect of differences concentration on the physical characteristics of edible film from native chicken claw gelatin. This study
\end{abstract}

*Korespondensi (corresponding author): Email: meitysompie@yahoo.com used a completely randomized design with the treatment of chicken claw gelatin concentration 5\%,10\%, 15 and 20\%, each treatment repeated four times. The results showed that the differences concentration of native chicken claw gelatin had significantly different effect $(\mathrm{P}<0.05)$ on the value of tensile strength, elongation and thickness of edible film. Based on the results of discussion, it can be concluded that the concentration of native chicken claw gelatin from variables with $10 \%$ gelatin concentration had good physical characteristics of edible film.

Keywords: Native chicken claw, Edible film Gelatin

\section{PENDAHULUAN}

Pengembangan edible film sebagai bahan pelapis maupun sebagai pengemas semakin meningkat, disebabkan semakin tingginya kesadaran manusia akan bahan pengemas yang dapat didegradasi menggantikan bahan plastik yang tidak dapat didegradasi. Selain itu edible film merupakan satu jenis kemasan yang bersifat ramah lingkungan, keuntungannya selain dapat melindungi produk pangan, dapat langsung dimakan serta aman bagi lingkungan. Edible film dibagi menjadi dua 
kelompok yaitu yang berfungsi sebagai pelapis (edible coating) dan yang berbentuk lembaran (film). Edible coating adalah lapisan tipis yang terbuat dari bahan pangan yang digunakan untuk melapisi makanan (coating) atau menempatkan diantara makanan (Ockerman dan Hansen, 2000).

Edible film merupakan lapisan tipis yang dapat dikonsumsi dan sering digunakan sebagai pelapis makanan. Keuntungan penggunaan edible film untuk kemasan bahan pangan adalah memperpanjang umur simpan produk serta tidak mencemari lingkungan karena edible film ini dapat dimakan bersama produk yang dikemasnya (Bourtoom, 2008).

Salah satu bahan baku pembuatan edible film adalah gelatin. Gelatin dibuat dari hasil ikutan yang dihasilkan dari pemotongan dan pengolahan ternak, seperti kulit dan tulang. Gelatin sangat penting dalam diversifikasi bahan makanan karena nilai gizinya yang tinggi terutama kadar protein khususnya asam amino dan rendahnya kadar lemak. Gelatin di Indonesia merupakan barang impor dengan negara pengekspornya adalah Eropa dan Amerika. Persentase aplikasi gelatin di bidang pangan mencapai $60 \%$ dari total gelatin impor sedang sisanya digunakan di bidang non pangan. Kontribusi gelatin dari sapi sebesar $33 \%$ dan $27 \%$ dari gelatin yang berasal dari babi sehingga gelatin yang berbahan baku kulit kaki ayam menjadi alternatif yang cukup potensial untuk dikembangkan, mengingat produksi ayam di Indonesia dari tahun ke tahun mengalami peningkatan seiring dengan bertambahnya jumlah penduduk dan pemenuhan gizi masyarakat Indonesia (Hasdar, 2011, Agustin dan Sompie, 2015).

Kaki ayam merupakan hasil ikutan pemotongan ayam yang pemanfaatannya terbatas karena sedikit daging, tinggi kandungan kulit dan tulangnya. Kulit dan tulang tersusun dari jaringan ikat padat yang kaya akan kolagen. Hidrolisis partikel kolagen akan menghasilkan gelatin. Dengan semakin meningkatnya jumlah populasi ternak ayam kampung atau unggas lokal di Indonesia khususnya di Sulawesi Utara kurun waktu lima tahun terakhir cenderung mengalami peningkatan. Data Direktorat Jenderal Peternakan dan Kesehatan Hewan (2017) menyatakan bahwa terjadi peningkatan populasi ayam kampung dari tahun ke tahun, pada tahun 2017 populasi ayam kampung sebanyak 1.698.369 ekor, sehingga di Indonesia akan tersedia hasil pemotongan ayam kampung berupa ceker ayam. Menurut Sompie et al. (2015) bahwa gelatin ceker ayam kampung yang menggunakan konsentrasi asam asetat 3\% dengan lama curring 24 jam menghasilkan kualitas gelatin yang baik yaitu nilai rendemen $12,31 \%$, kekuatan gel 64,16 g/Bloom, viskositas 5,50 cP, kadar protein $89,90 \%$ dan kadar air $7,31 \%$. 
Dengan kata lain, gelatin ceker ayam kampung dengan perlakuan tersebut dapat digunakan sebagai bahan dasar pembuatan edible film untuk diaplikasikan menjadi bahan pengemas daging yang berfungsi untuk mempertahankan berat dan menurunkan jumlah mikroorganisme yang mengkontaminasi permukaan daging. Penelitian mengenai edible film dari gelatin ceker ayam kampung belum banyak dilakukan. Berdasarkan hal tersebut diatas, maka telah dilakukan suatu penelitian tentang karakteristik fisik edible film yang berbahan dasar gelatin ceker ayam kampung sebagai bahan pengemas produk pangan.

\section{MATERI DAN METODE PENELITIAN}

\section{Materi Penelitian}

Bahan utama yang digunakan dalam penelitian ini adalah gelatin ceker ayam kampung, aquades dan gliserol. Peralatan yang digunakan dalam proses produksi edible film adalah: water bath, oven, timbangan analitik, pengaduk, labu erlenmeyer $1000 \mathrm{ml}$, thermometer, wadah teflon.

\section{Metode Penelitian}

Penelitian ini menggunakan Rancangan Acak Lengkap (RAL) dengan 4 perlakuan dan ulangan sebanyak empat kali menurut Steel dan Torrie (1993). Perlakuannya adalah konsentrasi gelatin yang disusun sebagai berikut :

$$
\begin{aligned}
& \mathrm{P}_{1}=5 \% \text { gelatin } \\
& \mathrm{P}_{2}=10 \% \text { gelatin } \\
& \mathrm{P}_{3}=15 \% \text { gelatin } \\
& \mathrm{P}_{4}=20 \% \text { gelatin }
\end{aligned}
$$

\section{Variabel Penelitian}

Variabel yang akan diamati dalam penelitian ini adalah :

1. Kekuatan tarik (Bourtoom, 2008).

2. Kemuluran (Bourtoom, 2008 dan Wittaya, 2013)

3. Ketebalan (Setiani et al., 2013)

\section{Prosedur Penelitian}

Pembuatan gelatin (Sompie et al., 2015). Bahan baku ceker ayam kampung, keluarkan kuku, lalu dipotong ceker ayam kampung dengan ukuran $2 \mathrm{~cm}$, dicuci dan dibersihkan, ceker yang telah dipotong kecil-kecil ditimbang lalu dituang ke wadah, ditambahkan aquades $1000 \mathrm{~mL}$ dan larutan asama asetat $\left(\mathrm{CH}_{3} \mathrm{COOH}\right)$ sebanyak $3 \%$ direndam selama 24 jam lalu disimpan di lemari es. Setelah itu cuci bersih dan tiriskan ceker yang telah direndam dengan asam asetat, kemudian salin ke Erlenmeyer lalu dihomogenisasi di dalam waterbath yang sudah dipanaskan pada suhu $55^{\circ} \mathrm{C}$ selama 5 jam, setelah itu larutan gelatin yang sudah diekstrasi disaring dengan kain 
dan dituang ke wadah yang sudah dilapisi plastik, lalu dikeringkan di dalam oven dengan suhu $60^{\circ} \mathrm{C}$ selama 24-48 jam, setelah itu angkat lembaran gelatin.

Pembuatan Edible Film (Sompie, et al., 2015). Lembaran gelatin ceker ayam kampung yang telah jadi kemudian dihaluskan menjadi serbuk, lalu ditimbang, setelah itu dilakukan konsentrasi gelatin sebanyak 5\%, 10\%, 15\%, 20\% dengan penambahan $100 \mathrm{ml}$ aquades diaduk di dalam waterbath selama 30 menit pada suhu $50^{\circ} \mathrm{C}$ setelah tercampur ditambahkan gliserol sebanyak $10 \%$ sebagai plasticizer, kemudian setelah tercampur, larutan edible film dituang ke wadah teflon lalu dikeringkan ke dalam oven selama 24 jam, setelah jadi edible film diangkat secara perlahan dan dianginkan.

\section{HASIL DAN PEMBAHASAN}

\section{Kekuatan Tarik}

Hasil analisis sidik ragam menunjukkan bahwa konsentrasi gelatin ceker ayam kampung memberikan pengaruh yang berbeda nyata $(\mathrm{P}<0.05)$ terhadap kekuatan tarik edible film. Hasil uji Duncan menunjukkan bahwa kekuatan tarik edible film dengan konsentrasi gelatin 5\% nyata lebih tinggi dari konsentrasi gelatin 10\%, 15\%, 20\%. Selanjutnya konsentrasi gelatin 10\% lebih tinggi dari $15 \%, 20 \%$ tetapi lebih rendah dari $5 \%$. Demikian juga edible film yang menggunakan konsentrasi gelatin $15 \%$ lebih tinggi dari $20 \%$ tapi lebih rendah dari $10 \%$ dan 5\%. Hal ini menunjukan bahwa semakin tinggi konsentrasi gelatin maka nilai kekuatan tarik edible film semakin kecil. Hal ini disebabkan oleh semakin meningkatnya konsentrasi gelatin dengan penambahan gliserol yang ditambahkan maka gaya interaksi antar matriks molekul yang terdapat dalam edible film semakin kuat, sehingga meningkatkan kekuatan tarik dari edible film yang dihasilkan. Menurut Rodriguez et al. (2006) mengemukakan bahwa penggunaan gliserol dapat meningkatkan fleksibilitas dan menurunkan gaya intermolekuler sepanjang rantai polimernya. Nilai kekuatan tarik pada penelitian ini adalah pada kisaran antara 0,696-3,849 MPa. Hasil ini hampir sama dengan hasil penelitian Hasdar et al. (2011) bahwa nilai kekuatan tarik berada pada kisaran antara 1,5-2,7 MPa. 
Tabel. Rataan Kekuatan Tarik, Kemuluran, Ketebalan

\begin{tabular}{lllll}
\hline Variabel & \multicolumn{4}{c}{ Konsentrasi Gelatin Ceker Ayam Kampung (\%+Sd) } \\
\cline { 2 - 5 } & \multicolumn{1}{c}{5} & 10 & 15 & 20 \\
\hline Kekuatan Tarik (MPa) & $3,85 \pm 0,11^{\mathrm{d}}$ & $1,63 \pm 0,41^{\mathrm{c}}$ & $1,02 \pm 0,59^{\mathrm{b}}$ & $0,69 \pm 0,50^{\mathrm{a}}$ \\
Kemuluran (\%) & $55,29 \pm 10,27^{\mathrm{a}}$ & $101,57 \pm 3,82^{\mathrm{b}}$ & $109,32 \pm 4,79^{\mathrm{b}}$ & $130,29 \pm 2,73^{\mathrm{c}}$ \\
Ketebalan (mm) & $0,25 \pm 0,01^{\mathrm{b}}$ & $0,21 \pm 0,02^{\mathrm{a}}$ & $0,36 \pm 0,01^{\mathrm{d}}$ & $0,31 \pm 0,04^{\mathrm{c}}$ \\
\hline
\end{tabular}

Keterangan : superskrip berbeda pada baris yang sama menunjukan perbedaan nyata $(\mathrm{P}<0.05)$;

$\mathrm{Sd}=$ Standar deviasi

\section{Kemuluran Edible Film}

Hasil analisis sidik ragam pada menunjukkan bahwa konsentrasi gelatin ceker ayam kampung memberikan pengaruh yang berbeda nyata $(\mathrm{P}<0.05)$ terhadap kemuluran edible film. Hasil uji Duncan menunjukkan bahwa kemuluran edible film dengan konsentrasi gelatin $20 \%$ nyata lebih tinggi dari $15 \%, 10 \%$ dan $5 \%$. Selanjutnya konsentrasi gelatin $15 \%$ sama dengan $10 \%$ tapi lebih tinggi dari 5\%, dan lebih rendah dari 20\%, sedangkan konsentrasi gelatin $10 \%$ lebih tinggi dari $5 \%$ tetapi lebih rendah dari $15 \%$ dan $20 \%$. Hal ini menunjukan bahwa setiap perlakuan konsentrasi gelatin mengalami kemuluran yang semakin meningkat, karena semakin tinggi nilai konsetrasi gelatinnya maka nilai kemuluran edible film semakin tinggi. Hal ini disebabkan karena perlakuan konsentrasi gelatin dengan penambahan gliserol yang meningkat dapat meningkatkan peregangan ruang intermolekul struktur matriks edible film dan meningkatkan fleksibilitas, sehingga mengurangi kerapuhan dan tidak mudah pecah. Nilai kemuluran edible film yang dihasilkan pada penelitian ini adalah berkisar antara 55,293-130,296\%. Nilai ini hampir sama dengan hasil penelitian peneliti terdahulu edible film dari gelatin kulit babi yaitu 38,147 - 62,286\% (Sompie et al., 2014) dan 54,051-95,117\% dari bahan baku gelatin kulit kambing (Said $e t$ al., 2011). Kemuluran dikatakan baik jika nilainya lebih dari $50 \%$ dan dikatakan buruk jika nilainya kurang dari 50\%.

\section{Ketebalan}

Hasil analisis sidik ragam pada menunjukkan bahwa konsentrasi gelatin ceker ayam kampung memberikan pengaruh yang berbeda nyata $(\mathrm{P}<0.05)$ terhadap ketebalan edible film. Hasil uji Duncan menunjukkan bahwa ketebalan edible film dengan konsentrasi gelatin 5\% lebih tinggi dari $10 \%$ tetapi lebih rendah dari $15 \%$ dan $20 \%$. Selanjutnya konsentrasi gelatin $10 \%$ lebih rendah dari 5\%,15\% dan $20 \%$, sedangkan konsentrasi gelatin $15 \%$ nyata lebih tinggi dari $20 \%, 10 \%$ dan $5 \%$. Hal ini berarti semakin tinggi nilai konsentrasi gelatin maka nilai ketebalan edible film lebih besar tetapi jika ketebalan 
edible film semakin tipis maka nilai ketebalan edible film semakin baik. Hal ini disebabkan oleh karena semakin tinggi perlakuan konsentrasi gelatin dengan penambahan gliserol akan meningkatkan total padatan larutan. Peningkatan jumlah total padatan dalam larutan menyebabkan ketebalan dari edible film semakin meningkat, peningkatan jumlah padatan mengakibatkan polimer yang menyusun matrik edible film semakin banyak (Nugroho et al., 2013). Nilai ketebalan edible film yang dihasilkan pada penelitian ini adalah berkisar antara 0,208-0,357 $\mathrm{mm}$. Ketebalan edible film ini hampir sama dengan standar Japanese Industrial Standart (1975) ketebalan edible film yang ada menurut Anisa Setyaningrum et al. (2017) yaitu maksimal memiliki ketebalan sebesar 0,25 mm. Ketebalan edible film pada hasil penelitian ini lebih tebal dibandingkan dengan beberapa hasil penelitian edible film dengan bahan yang berbeda. Nilai ketebalan yang diperoleh pada penelitian ini hampir sama dengan ketebalan edible film kulit babi dengan plasticizer menggunakan gliserol yakni 0,133 - 0,226 mm dan 0,247 - 0,326 mm dengan bahan dasar edible film gelatin kulit kambing (Said, 2011).

\section{KESIMPULAN}

Berdasarkan hasil pembahasan dapat disimpulkan bahwa penggunaan gelatin ceker ayam kampung dari semua variabel dengan konsentrasi gelatin $10 \%$ menghasilkan karakteristik fisik edible film yang baik.

\section{DAFTAR PUSTAKA}

Agustin A. T dan M. Sompie. 2015. Kajian Gelatin kulit ikan tuna (Thunnus albacore) yang diproses menggunakan asam asetat. Prossiding Seminar Nasional Masyarakat Biodiversitas Indonesia, 1 (5): 1186 1189.

Bourtoom, T. 2008. Plasticizer effect on the properties of biodegradable blend film from rice starch-chitosan. Journal Science Technology, 30 (1) : $149-165$.

Direktorat Jenderal Peternakan dan Kesehatan Hewan. 2017 Statistik Peternakan dan Kesehatan Hewan. Dirjen Peternakan Kementerian Pertanian. Hal 19. Tanggal akses. 13 November 2018. http://ditjenpkh.pertanian.go.id

Hasdar, M., Triatmojo, S., dan Erwanto, Y. 2011. Karakteristik Edible Film yang Diproduksi Dari Kombinasi Gelatin Kulit Kaki Ayam dan Soy Protein Isolate. Buletin Peternakan. Vol. 35(3): 188-196.

Japanese Industrial Standard. 1975. Japanese Industrial Standart 21707. Japanese Standart Association.Japan. Tanggal akses 23 Oktober 2018. http://www.researchgate.net/publicat ion/324253601 
Nugroho, A. A., Basito dan R. B. Katri. 2013. Kajian pembuatan Edible Film Tapioka dengan pengaruh penambahan pektin beberapa jenis kulit pisang terhadap karakteristik fisik dan mekanik. Jurnal Teknosains Pangan. 2(1): 73-79.

Ockerman, H.W and C.L. Hansen. 2000. Animal By product Processing and Utilization. CRCpress, USA.

Rodriguez, M, J, Oses, K, Ziani, and J,I Mate. 2006. Combined effect of plasticizer and surfactants on the physical properties of starch based edible films. Food Res. Int 39: 840846.

Said, M. I., S. Triatmojo, Y. Erwanto and A, Fudholi. 2011. Karakteristik gelatin kulit kambing yang diproduksi melalui proses asam basa, Journal Agritech 31(3): 190 - 200.

Setiani, W., T. Sudiarti, dan L. Rahmidar. 2013. Preparasi dan karakterisasi edible film dari poliblend pati sukunkitosan. Jurnal Teknosains Pangan, 3(2): 100 - 109.
Setyaningrum, A., N. K. Sumarni, dan J. Hardi. 2017. Sifat fisiko kimia Edible Film agar-agar rumput laut (Gracilaria Sp.) tersubtitusi glyserol. Natural Science: Journal of Science and Technology 6(2): 136-143.

Sompie, M., S. C. Rimbing, S.E. Surtijono dan F. Ratulangi, 2014. Pengaruh konsentrasi asam asetat dan suhu ekstraksi terhadap karakteristik gelatin kulit babi. Prossiding Seminar Nasional Himpunan Kimia Indonesia 1(1): $65-69$.

Sompie, M., S. E. Surtijono, J.W. Pontoh dan N. Lontaan., 2015. Effect of acetic acid concertration and temperature extraction on physical and chemical properties of pigskin gelatin. Procedia Food Journal Science 3(1): 383-388.

Steel dan Torrie, 1993. Principle and Procedure of Statictics. McGraw-Hill Book Co. Inc. New York.

Wittaya, T. 2013. Influence of type and concentration of plasticizer on the properties of edible film from mung bean proteins. Journal Food Science 13: $51-58$. 